\title{
Implementasi Peraturan Menteri Agama tentang Pengawas Madrasah dan Pengawas Pendidikan Agama Islam pada Sekolah dalam Meningkatkan Kinerja Guru Kota Bandung
}

\author{
Neneng Sunengsih ${ }^{1}$, Cahya Syaodih ${ }^{2}$, Suharyanto H Soro ${ }^{3}$
}

1,2,3Sekolah Pascasarjana, Universitas Islam Nusantara Bandung, Indonesia E-mail: nenengsunengsih081.47@gmail.com,syaodih1969@gmail.com, suharyantosoro@gmail.com

\section{Article Info \\ Article History \\ Received: 2021-10-09 \\ Revised: 2021-11-02 \\ Published: 2021-11-19}

\section{Keywords:}

Regulation;

Minister;

Religion;

Supervisor;

Madrasah Schools

Teacher Performance.

\begin{abstract}
In evaluating the results of the implementation of the supervision program carried out by supervisors on teacher performance, namely; carry out evaluations of the results of teacher and madrasah head coaching, evaluation of the implementation of teacher and/or madrasah principals' performance appraisals. Factors of weakness and obstacles for supervisors in improving teacher performance are the competence of supervisors who are still weak in the development of research fields, the workload of supervisors who are quite a lot, support for facilities and infrastructure for the benefit of supervisors' main functions, and not yet maximal bureaucratic support. Supporting factors for supervisors are the existence of PMA itself as a guide and legal umbrella for supervisors in carrying out their main tasks, supervisory competences that are quite capable in other fields and fully aware of their duties as supervisors, playing an active role as motivators, innovators, assessors, and as collaborators for teachers and principals. madrasah. The supervisor's solution is to increase self-competence by participating in intensive training, empowering and always coordinating with Pokjawasmad, PAIS, and MGMP groups, using approach techniques that are adapted to madrasa conditions. Conclusion on the PMA implementation research number 31 of 2013 in improving teacher performance Planning, Implementation and Evaluation of madrasa supervisors at PMA no 31 of 2013 in both madrasas has been running as expected, although not so optimal.
\end{abstract}

\begin{tabular}{l}
\hline Artikel Info \\
\hline Sejarah Artikel \\
Diterima: 2021-10-09 \\
Direvisi: 2021-11-02 \\
Dipublikasi: 2021-11-19
\end{tabular}

Kata kunci:

Peraturan;

Menteri;

Agama;

Pengawas;

Madrasah;

Kinerja Guru.

\begin{abstract}
Abstrak
Penelitian ini menggunakan pendekatan kualititatif dengan penelitian deskriptif, dengan Teknik pengumpulan data menggunakan wawancara, observasi terlibat dan dokumentasi, Teknik pengolahan data yang digunakan diantaranya: reduksi data, display data dan menarik kesimpulan, Lokasi penelitian adalah di 2 tempat jenjang Madrasah Aliyah swasta yang berada di Kota Bandung yakni MA Swasta Al-Inayah dan MA Swasta Nurul Iman, Pada evaluasi hasil pelaksanaan program pengawasan yang dilakukan pengawas pada kinerja guru yaitu; melaksanakan evaluasi hasil pembinaan guru dan kepala madrasah, evaluasi pelaksanaan penilaian kinerja guru dan/atau kepala madrasah. Faktor kelemahan dan hambatan pengawas dalam meningkatkan kinerja guru adalah kompetensi pengawas yang masih lemah pada pengembangan bidang penelitian, beban kerja pengawas yang cukup banyak, dukungan sarana dan prasarana untuk kepentingan tupoksi pengawas, dan belum maksimalnya dukungan birokrasi. Faktor pendukung pengawas yakni keberadaan PMA itu sendiri sebagai pedoman dan payung hukum pengawas dalam menjalankan tupoksinya, kompetensi pengawas yang cukup mumpuni pada bidang lain dan menyadari penuh akan tupoksinya sebagai pengawas, berperan aktif sebagai motivator, inovator, assesor, dan sebagai kolaborator para guru dan kepala madrasah. Solusi pengawas adalah meningkatkan kompetensi diri dengan mengikuti diklat secara intensif, memberdayakan dan selalu koordinasi dengan pokjawasmad, pais, dan kelompok MGMP, menggunakan teknik pendekatan yang disesuaikan dengan kondisi madrasah. Kesimpulan pada penelitian Implementasi PMA nomor 31 tahun 2013 dalam meningkatkan kinerja guru Perencanaan, Pelaksanaan dan Evaluasi pengawas madrasah pada PMA no 31 tahun2013 pada kedua madrasah tersebut sudah berjalan sesuai dengan harapan, walaupun belum begitu optimal.
\end{abstract}

\section{PENDAHULUAN}

Masalah pendidikan dalam situasi apapun tentunya membutuhkan penanganan intensif dari beberapa komponen pendidikan yakni guru, pengawas, kepala sekolah dan orang tua. Untuk mencapai mutu pendidikan yang maksimal, perlu diperhatikan semua komponen yang ada didalamnya, dan perlu upaya perbaikanperbaikan atau pembaharuan perkembangannya. 
Salah satu keberhasilan pendidikan ditentukan oleh komponen pengawasan. Dalam hal ini pengawas yang wilayah kepengawasannya berada pada lingkup madrasah. Pengawas merupakan tenaga kependidikan sebagai perpanjangan tangan yang bertugas untuk meningkatkan kinerja guru melalui pembimbingan, pembinaan dan pengembangan kompetensi dan profesionalisme guru sehingga tercapai mutu pendidikan di sekolah/madrasah. Pengawas memiliki peran melakukan kegiatan pemantauan, penilaian, pengawasan dan pembinaan terhadap kinerja guru dalam melaksanakan pembelajaran, serta terhadap kepala sekolah/ madrasah, staf madrasah dalam kegiatan administratif dalam pengelolaan madrasah agar lebih baik kinerjanya.

Pengawas sekolah/madrasah sebagai bagian dalam proses mencapai pendidikan yang bermutu, karenanya mutu pengawas akan mempengaruhi mutu guru, mutu guru akan mempengaruhi mutu proses pembelajaran, proses pembelajaran yang bermutu akan menghasilkan peserta didik yang bermutu, dan pada akhirnya jika semua itu bersinergi akan mempengaruhi mutu pendidikan secara keseluruhan. Kepengawasan secara efektif memerlukan keterampilan, tanggung jawab, kemampuan, dan keaktifan dalam pelaksanaan tugas masingmasing. Proses pengawasan akan dapat mendeteksi sedini mungkin berbagai hambatan yang dihadapi pelaksanaan program pendidikan disekolah, sehingga bisa dicarikan jalan keluar atau solusi dari hambatan tersebut. Untuk mewujudkan pengawasan pendidikan yang efektif maka sangat erat kaitannya dengan keberadaan pengawas pendidikan dalam melaksanakan tupoksinya.

Deregulasi aturan dan tupoksi pengawas tercantum pada Peraturan Menteri Agama, No. 31 Tahun 2013, Pengawas madrasah dengan melaksanakan pengawasan secara manajerial pada satuan pendidikan yang meliputi penyusunan program pengawasan, pelaksanaan, pembinaan, penilaian, pembimbingan dan pelatihan profesional guru, evaluasi hasil pelaksanaan program pengawasan, dan pelaksanaan tugas kepengawasan di daerah khusus, dan pemantauan pelaksanaan 8 (delapan) Standar Nasional Pendidikan yang terdiri dari: (1) standar kompetensi lulusan, (2) standar isi, (3) standar proses, (4) standar pendidikan dan tenaga kependidikan, (5) standar sarana dan prasarana, (6) standar pengelolaan, (7) standar pembiayaan pendidikan, (8) standar penilaian pendidikan.

Program peningkatan mutu pendidikan di Madrasah dapat dicapai apabila kegiatan pendidikan dan pembelajaran di sekolah berlangsung dengan baik, dan berdaya guna. Hal tersebut dapat terlaksana apabila ditunjang dengan adanya upaya peningkatan kemampuan personil pendidikan di madrasah. Salah satu personil yang berpengaruh sangat penting dalam dunia pendidikan Indonesia adalah keberadaan guru sebagai pendidik dan pengajar yang akan mengarahkan generasi bangsa ke arah yang benar dan tepat. Guru merupakan bagian terpenting dalam proses belajar mengajar, begitu pula pada Madrasah.

Madrasah adalah sekolah umum berciri khas agama Islam, yang muatan kurikulumnya sama dengan sekolah non madrasah, akan tetapi madrasah muatan kurikulumnya lebih dominan dengan pembelajaran keagamaannya. Madrasah adalah suatu institusi pendidikan yang dalam proses kerjanya selalu dihadapkan dengan kondisi input dan lingkungan yang tidak sama, karena madrasah di bawah Kementerian Agama. Dalam situasi demikian, maka praktik pengawasan di madrasah menjadi indikator yang sangat penting bahwa pengawasan merupakan fungsi administrasi untuk menjamin agar kegiatan yang dilakukan sesuai dengan apa yang telah ditetapkan atau diinginkan. Pengawasan di madrasah mempunyai peran yang sangat penting, baik dilakukan oleh kepala madrasah ataupun oleh pengawas, pengawasan dilakukan dalam upaya menjamin mutu pendidikan pada madrasah, khususnya dalam rangka pencapaian standar nasional pendidikan. Namun dalam implementasinya di lapangan, fungsi pengawasan ini belum mampu memberikan peningkatan kualitas pendidikan di madrasah khususnya berkaitan dengan kinerja guru madrasah. Terlebih bagi madrasah-madrasah yang ada di daerah. Tantangan kepengawasan pendidikan di madrasah juga muncul dengan berkembangnya globalisasi pendidikan yang secara otomatis menuntut pengawas madrasah untuk cepat tanggap dalam merespon perubahan untuk menularkannya kepada madrasahmadrasah binaannya.

Berdasarkan uraian diatas tentang berbagai problematika yang ada pada dunia pendidikan, penulis tertarik melakukan penelitian pada dua madrasah di Kota Bandung yakni Madrasah Aliyah Swasta Nurul Iman dan Madrasah Aliyah Swasta Al Inayah karena kedua Madrasah 
tersebut merupakan madrasah swasta yang berada dibawah kementrian Agama Kota Bandung, yang tergolong ungggul dari sisi kualitas dan kuantitas.

\section{METODE PENELITIAN}

Metode penelitian ini yaitu menggunakan pendekatan kualititatif dengan penelitian deskriptif. Dapat dikatakan bahwa penelitian deskriptif merupakan penelitian yang berusaha mendeskripsikan suatu gejala, peristiwa yang terjadi pada saat sekarang atau masalah actual, Lokasi penelitian adalah di 2 tempat jenjang Madrasah Aliyah swasta yang berada di Kota Bandung yakni MA Swasta Al-Inayah dan MA Swasta Nurul Iman Kedua sekolah tersebut berada di wilayah Kota Bandung dan di bawah Kementrian Agama Kota Bandung, adapun Teknik pengumpulan data yang digunakan dalam penelitian ini menggunakan teknik pengumpulan data wawancara, observasi terlibat dan dokumentasi, sedangkan Teknik pengolahan data yang digunakan dalam penelitian ini adalah reduksi data, display data dan menarik kesimpulan.

\section{HASIL DAN PEMBAHASAN}

\section{A. Hasil Penelitian}

1) Madrasah Aliyah Swasta Al Inayah

a. Perencanaan Pengawas Madrasah dalam Implementasi Peraturan Menteri Agama Nomor 31 Tahun 2013 dalam meningkatkan kinerja guru

Pengawas telah menyusun Rencana program Kerja kepengawasan yang digunakan sebagai acuan dalam melaksanakan kegiatan pengawasan karena di dalamnya terdapat alur kerja yang digunakan sebagai pedomana pelaksanaan kegiatan kepengawasan. Dalam kegiatan perencanan Pengawas madrasah membuat program tahunan yang tertuang didalam Rencana Kerja Tahunan atau RKP. Rencana kerja tahunan inilah digunakan pengawas sebagai acuan dalam melakukan pengawasan di madrasah binaan yakni salah satunya yaitu MAS Al Inayah. Pengawas melaksanakan tugas pengawasan akademik dan manajerial. Pengawasan Akademik merupakan tugas pengawas yang berkenaan dengan pelaksanaan tugas pembinaan, pemantauan, penilaian, dan pembimbingan dan pelatihan profesional guru pada aspek kompetensi guru dan tugas pokok guru. Pengawasan Manajerial merupakan tugas pengawas yang berkenaan dengan pelaksanaan tugas pembinaan, pemantauan, penilaian, dan pembimbingan dan pelatihan profesional kepala madrasah dan tenaga kependidikan lain pada aspek pengelolaan dan administrasi sekolah yang terkait langsung dengan efisiensi dan efektivitas madrasah dalam mendukung terlaksananya proses pembelajaran. Dua tugas pengawasan akademik dan manajerial ini tertuang dalam program tahunan dan program semester pengawas yang secara rutin dibuat oleh pengawas pada awal tahun pelajaran / tahun anggaran. Dalam melakukan pembimbingan, pembinaan, dan pengembangan pengawas selalu mengacu pada Pedoman Kerja Pengawas yaitu : (1) Program Tahunan dan Program Semester Rencana Pengawasan Akademik dan Rencana Pengawasan Manajerial; (2) Instrumen Monitoring dan Evaluasi Kepengawasn (3) Pedoman Penilaian kinerja guru dan kepala madrasah Program kerja yang dibuat oleh pengawas untuk setiap madrasah berbeda, karena setiap lembaga memiliki visi, misi, dan kondisi real yang berbeda. Program kerja yang dibuat disesuaikan dengan kebutuhan setiap madrasah binaan. Contohnya pada MAS Al Inayah dibuat berbeda dengan yang akan diberikan pada MAS Nurul Iman.

Program kerja yang berkaitan dengan pembimbingan dan pelatihan profesional guru meliputi : Program perencanaan pembelajaran, pelaksanaan pembelajaran, pelaksanaan penilaian hasil pembelajaran, pembimbingan dan pelatihan tugas tambahan, dan pembimbingan pelatihan pengembangan profesi dan publikasi ilmiah, aspek-aspek yang menjadi bahan pembinaan oleh pengawas Madrasah terhadap madrasah Al Inayah adalah: (1) Perencanaan Pembelajaran (2) Pelaksanaan pembelajaran (3) Penilaian hasil belajar, yang selanjutnya dijadikan bahan sebagai materi pembinaan.

b. Pelaksanaan Pengawas Madrasah dalam Implementasi Peraturan Menteri Agama Nomor 31 Tahun 2013 dalam meningkatkan kinerja guru

Pengawas Madrasah dalam melaksakan program kepengawasan salah satunya melakukan kegiatan visitasi, tujuan utama dan prioritas yg dikerjakan adalah melakukan pemantauan untuk mengetahui 
keterlaksanaan atau kesesuaian pelaksanaan/ penyelenggaraan pendidikan dengan rencana, program, dan/atau Standar Nasional Pendidikan serta menemukan hambatan-hambatan dalam pelaksanaan program yang sudah dibuat. Pelaksanaan pengawasan yang dilakukan pengawas cukup aktif dan dapat dikatakan sesuai dengan perencanaan program yang sudah ditetapkan karna dekatnya jarak tempat tinggal pengawas dengan madrasah tersebut, dan yang lebih mendukung lagi pengawas yang bersangkutan awal karirnya adalah salah satu guru di MA Al Inayah, sehingga ada kedekatan secara psikologis lebih loyal terhadap madrasah dan lebih dekat dengan kepala madrasah.

Metode dan teknik yang digunakan pengawas dalam melakukan kegiatan supervisi akadamik dan manajerial terhadap kepala Madrasah dan guru, yakni menggunakan Supervisi Individual dan supervisi kelompok. Pada supervisi individual biasanya melakukan kunjungan kelas ketika guru sedang melaksanakn KBM, kunjungan observasi langsung ketika pengawas datang untuk melakukan pembinaan dan memeriksa beberapa hasil bimbingan yang pernah dilakukan pada periode lalu, misalnya dalam pembuatan administrasi pembelajaran. Dalam melakukan kunjungan langsung ke kelas pengawas selalu memberitahukan terlebih dahulu dan memeriksa terlebih dahulu kelengkapan administrasi guru tersebut.

Pengawas datang melakukan visitasi bertemu dengan guru-guru langsung secara individual ketika ada guru yang meminta berkonsultasi yang berkaitan dengan hambatan - hambatan atau ada ketidakfahaman pada pembuatan administrasi maupun proses kegiatan belajar mengajar. Pada supervisi kelompok, Pengawas selalu memberikan pembinaan pada pertemuan pertemuan atau rapatrapat koordinasi guru-guru, memberikan bimbingan dan mengadakan diskusi dengan kepala madrasah dan guru-guru, serta memberikan pembinaan kepada kelompok2 MGMP, ikut serta dalam pengadaan IHT. Langkah-langkah atau tahapan tahapan pengawas dalam melakukan pembinaan pada MAS Al Inayah yang berkaitan dengan kinerja guru adalah (1) Menyusun program pembimbingan dan pelatihan professional guru (2) Melaksanakan pembimbingan dan pelatihan profesional guru(3) Menyusun laporan hasil pembimbingan dan pelatihan profesional guru Mengevaluasi hasil pembimbingan dan pelatihan profesional guru.

c. Evaluasi pengawas madrasah pada Implemetasi P.M.A. Nomor 31 tahun 2013 dalam meningkatkan kinerja guru

Pengawas melakukan evaluasi dalam kegiatan membimbing dan membina guru adalah tugas wajib dan melekat bagi pengawas, evaluasi yang dilakukan pengawas sebagai koreksi terhadap hasil pelaksanaan program pengawasan. Temuan hasil evaluasi pelaksanaan pembinaan guru agar bisa digunakan sebagai masukan untuk bahan pembinaan keakademikan kepada guru yang bersangkutan. Adapun pembahasan hasil pembinaan guru yang terdapat pada lampiran hasil studi dokumentasi adalah sebagai berikut. Hasil pembinaan guru mengenai ketersediaan dokumen administrasi perencanaan pembelajaran, guru yang mampu sebanyak 18 orang guru, yang cukup mampu 9 orang guru, yang belum mampu sebanyak 2 orang guru, dan yang tidak mampu sebanyak 1 orang guru. Teknik dan metoda dalam melakukan pembinaan di lapangan sudah sesuai dengan tujuan yang diharapkan dalam kepengawasan walaupun belum mendapatkan hasil yang maksimal, dikarenakan padatnya jadwal di luar seoarang pengawas yang berperan juga sebagai asesor Sekolah BAN-S/M Jawa Barat. Beberapa guru juga merasakan adanya pengetahuan dan keterampilan dalam mempersiapkan administrasi dan kegiatan belajar mengajar. Dengan supervisi individual dan kelompok dapat meningkatkan kinerja guru secara signifikan dikarenakan adanya kedekatan pengawas dengan kepala sekolah dan beberapa guru yang bersifat kolegial dan sejawat, hal ini disebabkan ada riwayat bahwa pengawas tersebut pernah menjadi guru IPA pada MAS Al Inayah selama 3 tahun, sehingga guru-guru maupun pengawas itu sendiri sudah tidak segan dan lebih kepada pendekatan kekeluargaan ketika melakukan pembinaan dan pembimbingan. Mekanisme pelaporan 
hasil kerja pengawas madrasah pada lingkungan Kementerian Agama Kota Bandung. Setiap tahun pengawas madrasah melakukan evaluasi hasil pelaksanaan program pengawasannya, dan memberikan rekomendasi dan tindak lanjut yang harus dilakukan terhadap berbagai temuan hasil pelaksanaan programnya. Rincian tupoksi dan kompetensi Pengawas pada PMA Nomor 31 tahun 2013 yang di laksanakan pada MAS Al Inayah sudah dilakukan dengan baik terutama dalam melakukan upaya meningkatkan kinerja guru, yakni Pembinaan kepada guru (Kompetensi pedagogis, profesional, kepribadian, dan sosial), Pemantauan kinerja guru (Standar kelulusan, Standar isi, Standar Proses, Standar Penilaian), Penilaian Kinerja Guru (PKG) serta Pembimbingan dan pelatihan profesional guru. Sarana dan prasarana yang digunakan pengawas untuk pembinaan dan pembimbingan guru disesuaikan dengan sarana dan prasarana yang dimiliki madrasah. Akan tetapi peralatan IT pengawas selalu membawa sendiri, karena biasanya evaluasi dan penilaian selalu langsung dikerjakan untuk memenuhi tugas pelaporan.

d. Faktor- faktor dominan yang menjadi hambatan dan kekuatan pengawas madrasah pada Implementasi P.M.A. Nomor 31 tahun 2013 dalam meningkatkan kinerja guru

Faktor-faktor dominan yang menjadi kelemahan dan hambatan sebagai pengawas Madrasah pada implementasi PMA no 31 tahun 2013 dalam meningkatkan kinerja guru adalah Dukungan sarana dan prasarana untuk kepentingan tupoksi pengawas, Dukungan dari biroksari yang sangat kurang. Misalnya untuk tingkat kota, masih belum jelas posisi atau keberadaan struktur organisasi kepengawasan pada Unit Organisasi Pendidikan Madrasah Kota tersebut. Beban kerja pengawas yang cukup banyak, ditambah lagi dengan peran pengawas diluar karir seperti pada pengawas MAS Al Inayah sebagai asesor Sekolah BAN-S/M Jawa Barat. Ada kesenjangan dan keseganan dalam mensupervisi kepala sekolah ketika usia dan pengalaman kepala sekolah lebih senior dibandingkan dengan pengawas itu sendiri. Pengawas merasa terbatas dalam menyampaikan substansi materi, ketika guru bertanya tentang isi materi dan berharap ada pengembangan dari materi tersebut, karena latar belakang dari pengawas tersebut berbeda mapel yang diampunya. Faktor faktor dominan yang menjadi kekuatan dan pendukung pengawas Madrasah pada implementasi PMA No. 31 Tahun 2013 dalam meningkatkan kinerja guru adalah

Deregulasi aturan dari PMA No. 31 Tahun 2013 dan pedoman pedoman kepengawasan lainnya yang cukup jelas sebagai acuan kinerja pengawas dalam melaksanakan kegiatan pemantauan, pemotretan pembinaan dan evaluasi terhadap kinerja guru. Kompetensi pengawas yang cukup mumpuni dan menyadari penuh akan tupoksinya sebagai pengawas, berperan aktif sebagai motivator, inovator, assesor, dan sebagai kolaborator para Guru dan kepala madrasah. Dengan bekal keaktifan pengawas sebagai asesor Sekolah BAN-S/M jawa barat selalu mendapatkan informasi yang lumayan cepat, dan dapat secara langsung mensosialisasikan apa yang harus disiapkan ketika akan menghadapi akreditasi, atau penilaian kinerja guru. Selain ada kedekatan dari sisi emosional dengan kepala madrasah dan guru, jarak antar rumah tinggal dan tempat madrasah binaan cukup dekat hanya $3 \mathrm{~km}$ sehingga memudahkan dalam pemantauan.

e. Solusi pengawas madrasah pada Implementasi P.M.A. Nomor 31 tahun 2013 dalam meningkatkan kinerja guru

Selalu meningkatkan kompetensi pengawas dengan terus belajar dan mengikuti diklat kepengawasan, serta mengadakan study banding dengan pokjawas kota lain Pengawas mengalokasikan dana pribadi untuk melaksanakan program-progam Pokjawas dan kepengawasan, Beban kerja pengawas yang cukup banyak, solusinya adalah memaksimalkan forum MGMP dan kelompok binaan, berkoordinasi dengan Pokjawas Kota bandung membuat jaringan yang kuat antara POKJAWAS, Seksi PAIS, dan MGMP dalam membuat program peningkatan profesionalitas Guru dan Pengawas. Solusi pengembangan materi pengawas terus 
bekerja sama dan selalu koordinasi dengan MGMP.

\section{2) Madrasah Aliyah Swasta Nurul Iman}

a. Perencanaan Pengawas Madrasah dalam Implementasi Peraturan Menteri Agama Nomor 31 Tahun 2013 dalam meningkatkan kinerja guru

Temuan dalam penelitian ini menunjukkan, bahwa peran kepengawasan yang dilakukan oleh pengawas dalam implementasi PMA No. 31 tahun 2013 Kota Bandung adalah merencanakan dan menyiapkan perangkat kepengawasannya sebelum melakukan Pembinaan, pembimbingan dan pengembangan. Perangkat kepengawasan tersebut terhimpun dalam program tahunan, semester dan bulanan. Pada setiap awal tahun ajaran pengawas sudah mempersiapkan dan menyusun program dimaksud, sebelum pelaksanaan sudah berkoordinasi dengan kepala madrasah, dalam program tersebut tercermin secara jelas bagaimana kiat-kiat atau upaya yang dapat dianggap sebagai langkah strategis dapat meningkatkan kinerja guru. Perencanaan pengawas madrasah kota Bandung pada MAS Nurul Iman telah menyusun Rencana program Kerja kepengawasan yang digunakan sebagai acuan dalam melaksanakan kegiatan pengawasan karena di dalamnya terdapat alur kerja yang digunakan sebagai pedomana pelaksanaan kegiatan kepengawasan pada MAS Nurul Iman di Kementrian Agama Kota Bandung. Dalam kegiatan perencanan Pengawas madrasah membuat program tahunan yang tertuang didalam Rencana Kerja Tahunan atau RKP. Rencana kerja tahunan inilah digunakan pengawas sebagai acuan dalam melakukan pengawasan di madrasah binaan yakni salah satunya yaitu MAS Nurul Iman.

b. Pelaksanaan Pengawas Madrasah dalam Implementasi Peraturan Menteri Agama Nomor 31 Tahun 2013 dalam meningkatkan kinerja guru

Pengawas Madrasah dalam menjalankan programnya melakukan kegiatan visitasi, tujuan utama dan prioritas yg dikerjakan adalah melakukan pemantauan untuk mengetahui keterlaksanaan atau kesesuaian pelaksanaan/penyelenggaraan pendidikan dengan rencana, program, dan/atau Standar Nasional Pendidikan serta menemukan hambatan-hambatan dalam pelaksanaan program yang sudah dibuat. Pelaksanaan pengawasan yang dilakukan pengawas cukup aktif dan dapat dikatakan sesuai dengan perencanaan program yang sudah ditetapkan karna dekatnya jarak tempat tinggal pengawas dengan madrasah tersebut, dan yang lebih mendukung lagi pengawas yang bersangkutan awal karirnya adalah salah satu guru di MA Al Inayah, sehingga ada kedekatan secara psikologis lebih loyal terhadap madrasah dan lebih dekat dengan kepala madrasah. Metoda dan teknik yang digunakan pengawas dalam melakukan kegiatan supervisi akadamik dan manajerial terhadap kepala Madrasah dan guru, yakni menggunakan Supervisi Individual. Pada supervisi individual biasanya melakukan kunjungan kelas ketika guru sedang melaksanakn KBM, kunjungan observasi langsung ketika pengawas datang untuk melakukan pembinaan dan memeriksa beberapa hasil bimbingan yang pernah dilakukan pada periode lalu, misalnya dalam pembuatan administrasi pembelajaran. Dalam melakukan kunjungan langsung ke kelas pengawas selalu memberitahukan terlebih dahulu dan memeriksa terlebih dahulu kelengkapan administrasi guru tersebut. Pengawas datang melakukan visitasi bertemu dengan guru guru langsung secara individual ketika ada guru yang meminta berkonsultasi yang berkaitan dengan hambatan-hambatan atau ada ketidakpahaman pada pembuatan administrasi maupun proses kegiatan belajar mengajar.

Pada supervisi kelompok, Pengawas selalu memberikan pembinaan pada pertemuan pertemuan atau rapat-rapat koordinasi guru-guru, memberikan bimbingan dan mengadakan diskusi dengan kepala madrasah dan guru-guru, serta memberikan pembinaan kepada kelompok-kelompok MGMP, ikut serta dalam pengadaan IHT. langkah-langkah atau tahapan tahapan pengawas dalam melakukan pembinaan pada MAS Nurul Iman yang berkaitan dengan kinerja guru adalah (1) Menyusun program pembimbingan dan pelatihan profesional guru (2) Melaksanakan pembimbingan dan pelatihan profesional guru (3) Menyusun laporan hasil pembimbingan dan pelatihan 
profesional guru Mengevaluasi hasil pembimbingan dan pelatihan profesional guru.

c. Evaluasi pengawas madrasah pada Implemetasi P.M.A. Nomor 31 tahun 2013 dalam meningkatkan kinerja guru

Pengawas melakukan evaluasi dalam kegiatan membimbing dan membina kinerja guru adalah tugas wajib dan melekat bagi pengawas, evaluasi yang dilakukan pengawas sebagai koreksi terhadap hasil pelaksanaan program pengawasan. Evaluasi hasil pelaksanaan program pengawasan yang dilakukan pengawas meliputi empat hal, yaitu (1) Melaksanakan evaluasi hasil pembinaan guru dan kepala madrasah, (2) melaksanakan evaluasi hasil pelaksanaan pemantauan SNP, (3) melaksanakan evaluasi pelaksanaan penilaian kinerja guru dan/atau kepala madrasah, dan (4) melaksanakan evaluasi hasil pelaksanaan program pengawasan di tingkat kabupaten/ kota/provinsi. Kesesuaian antara program yang dibuat dengan visi misi setiap madrasah berbeda-beda; berdasarkan evaluasi ada yang sudah berhasil mencapai target ada juga yang masih belum berhasil, dan dalam proses.

d. Faktor- faktor yang menjadi hambatan dan kekuatan pengawas madrasah pada Implementasi P.M.A. Nomor 31 tahun 2013 dalam meningkatkan kinerja guru

Faktor faktor dominan yang menjadi kelemahan dan hambatan sebagai pengawas Madrasah pada implementasi PMA no 31 tahun 2013 dalam meningkatkan kinerja guru adalah Dukungan dari biroksari yang sangat kurang. Misalnya untuk tingkat kota, masih belum jelas posisi atau keberadaan struktur organisasi kepengawasan pada Unit Organisasi Pendidikan Madrasah Kota tersebut. Beban kerja pengawas yang cukup banyak, ditambah lagi dengan peran pengawas di luar karir seprti pada pengawas MAS Nurul Iman sebagai asesor Sekolah BAN-S/M Jawa Barat. Kurang ada kedekatan dari sisi emosional dengan guru dan kepala madrasah Pengawas merasa terbatas dalam menyampaikan substansi materi, ketika guru bertanya tentang isi materi dan berharap ada pengembangan dari materi tersebut, karena latar belakang dari pengawas tersebut berbeda mata pelajaran yang diampunya. Jarak tempuh dari rumah tinggal yang cukup lumayan jauh. Faktor dominan yang menjadi kekuatan dan pendukung pengawas Madrasah pada implementasi PMA No. 31 Tahun 2013 dalam meningkatkan kinerja guru adalah Deregulasi aturan dari PMA No. 31 Tahun 2013 dan pedoman pedoman kepengawasan lainnya yang cukup jelas sebagai acuan kinerja pengawas dalam melaksanakan kegiatan pemantauan, pemotretan dan pembinaan dan evaluasi terhadap kinerja guru. Kompetensi pengawas yang cukup mumpuni dan menyadari penuh akan tupoksinya sebagai pengawas, berperan aktif sebagai motivator, inovator, assesor, dan sebagai kolaborator para Guru dan kepala madrasah. Dengan bekal keaktifan pengawas sebagai asesor Sekolah BAN-S/M Jawa Barat selalu mendapatkan informasi yang lumayan cepat, dan dapat secara langsung mensosialisasikan apa yang harus disiapkan ketika akan menghadapi akreditasi, atau penilaian kinerja guru.

e. Solusi pengawas madrasah pada Implementasi P.M.A. Nomor 31 Tahun 2013 dalam meningkatkan kinerja guru

Selalu meningkatkan kompetensi diri sebagai pengawas dengan terus belajar dan mengikuti diklat kepengawasan, serta mengadakan study banding dengan pokjawas kota lain Pengawas mengalokasikan dana pribadi untuk melaksanakan program-progam Pokjawas dan kepengawasan, Beban kerja pengawas yang cukup banyak, solusinya adalah memaksimalkan forum MGMP dan kelompok binaan, berkoordinasi dengan Pokjawas Kota Bandung membuat jaringan yang kuat antara POKJAWAS, Seksi PAIS, dan MGMP dalam membuat program peningkatan profesionalitas Guru dan Pengawas. Sebelum melaksanakan tugasnya pengawas harus melakukan pendekatan secara humanis dan kekeluargaan terhadap guru guru binaannya. Solusi pengembangan materi pengawas terus bekerja sama dan selalu koordinasi dengan MGMP. Dalam penjadwalan harus menyediakan waktu khusus untuk madrasah yang jaraknya cukup lumayan jauh 


\section{B. Pembahasan}

a. Perencanaan Pengawas Madrasah dalam Implementasi Peraturan Menteri Agama Nomor 31 Tahun 2013 dalam meningkatkan kinerja guru

Perencanaan Pengawas pada PMA No. 31 tahun 2013 Pada Implementasi PMA no 31 tahun 2013 pengawas harus betul-betul membuat sebuah perencanaan yang matang dan bersifat dinamis. Artinya di dalam perencanaan tersebut berisi tentang model pendekatan yang selama ini digunakan diupayakan untuk ditingkatkan sehingga guru betul- betul merasakan sesuatu yang dinamis dalam pembinaan. Koonts (2014:8). Perencanaan merupakan suatu cara pandang yang logis mengenai apa yang ingin dilakukan, bagaimana cara melakukannya dan bagaimana cara mengetahui apa yang akan dilakukan. pengawas dalam proses perencanaan mempunyai pedoman kerja dan mengetahui dengan jelas apa yang harus dilakukan. Dalam membuat perencanaan kerja di bidang supervisi pendidikan ada beberapa langkah yang diperhatikan pengawas antara lain: Melakukan identifikasi masalah; Mengolah dan menganalisis hasil identifikasi masalah; Merumuskan perencanaan kerja pengawas; dan Menilai efektivitas pelaksanaan program kegiatan supervisi berdasarkan tujuan-tujuan yang telah ditetapkan hal ini sejalan dengan pendapat Endang Soenarya (2005:52). Dari uraian di atas dapat diketahui apapun kegiatan yang dilakukan, termasuk dalam bidang supervisi membutuhkan perencanaan yang jelas agar kegiatan itu dapat berhasil dan berdaya guna sehingga tidak menimbulkan kekecewaan, hal ini sejalan dengan pendapat Menurut Moh. Rifa'i (2005:48).

Program tahunan, semester maupun bulanan atau bahkan mingguan, merupakan tugas rutin pengawas. Pengawas madrasah membuatnya pada setiap awal tahun ajaran sebelum melaksanakan supervisi. Sebab program tersebut merupakan rujukan setiap saat bagi pengawas dalam melaksanakan tugasnya terlebih lagi dalam menyusun langkah-langkah strategis kepengawasan guna meningkatkan kinerja guru madrasah. Melalui program tersebut sudah tercermin dan sangat menentukan bagaimana model pendekatan pembinaan nantinya yang akan dilakukan oleh pengawas. Dari uraian di atas dapat disimpulkan pengawas sudah melaksanakan salah satu tufoksinya yang terdapat pada PMA No. 31 Tahun 2013, BAB II; pasal 4.

b. Pelaksanaan Pengawas Madrasah dalam Implementasi Peraturan Menteri Agama Nomor 31 Tahun 2013 dalam meningkatkan kinerja guru

Teknik yang digunakan dalam supervisi akademik merupakan sebuah strategi kepengawasan yang harus dikembangkan untuk menjadikan guru lebih profesional di bidangnya. Untuk meningkatkan profesional guru seorang Supervisor tidak hanya menggunakan satu teknik supervise saja, akan tetapi harus dicoba dengan teknik lain untuk menyesuaikan dengan keadaan dan tujuan yang ingin dicapai. Teknik yang digunakan pengawas pada pelaksanaan kepengawasan akademik terhadap guru menggunakan teknik- teknik yang bersifat individual, teknik individual adalah teknik yang dilaksanakan untuk seorang guru secara individual. Teknik seperti ini dilakukan berupa kunjungan kelas atau observasi kelas, percakapan pribadi, intervisitasi, menyeleksi berbagai sumber materi untuk mengajar dan menilai diri sendiri. Sedangkan yang bersifat kelompok adalah teknik yang dilakukan untuk melayani lebih dari satu orang. Misalnya pertemuan oreintasi bagi guru baru, panitia penyelenggara, rapat guru, studi kelompok antar guru,diskusi kelompok, tukar menukar pengalaman (sharing of experience) lokakarya (workshop), diskusi panel, seminar, simposium, demonstrasi mengajar, dan sebagainya. Dari uraian di atas sejalan dengan pendapat Sahertian (2010:52).

c. Evaluasi Pengawas Madrasah dalam Implementasi Peraturan Menteri Agama Nomor 31 Tahun 2013 dalam meningkatkan kinerja guru

Evaluasi hasil pelaksanaan program pengawasan yang dilakukan pengawas meliputi empat hal, yaitu (1) Melaksanakan evaluasi hasil pembinaan guru dan kepala madrasah, (2) melaksanakan evaluasi hasil pelaksanaan pemantauan SNP, (3) melaksanakan evaluasi pelaksanaan penilaian kinerja guru dan/atau kepala madrasah, dan (4) melaksanakan evaluasi hasil pelaksanaan program pengawasan di tingkat kabupaten/ kota/provinsi. Hal ini Sesuai dengan Pedoman yang dipakai pada PMA No. 31 Tahun 2013 tentang tupoksi pengawas madrasah. 
Kesesuaian antara program yang dibuat dengan visi misi setiap madrasah berbedabeda; berdasarkan evaluasi, ada yang sudah berhasil mencapai target ada juga yang masih belum berhasil, dan dalam proses. Program kepengawasan yang sudah dibuat ada yang sudah sesuai dan sinkron dengan jadwal yang sudah dibuat pengawas dan berjalan sesuai perencanaan, karena keterbatasan waktu pengawas dan banyaknya kegiatan di sekolah sehingga terjadi penumpukan kegiatan pada satu waktu sehingga program kegiatan ada yang belum bisa terlaksana apa yang sudah direncanakan. Hasil evaluasi ini akan dipakai sebagai rujukan rencana tindak lanjut pengawas dalam membuat program berikutnya. Dalam menjalankan fungsinya sebagai Pengawas untuk melakukan controling secara terus menerus dan berkelanjutan untuk mencapai tujuan dalam pendidikan. Dari pembahasan di atas pengawas dalam menjalankan fungsi dan kewajibannya dalam membimbing dan membina kinerja guru sudah melakukan dua pendekatan kepengawasan yakni kepengawasan sistem tradisional dan pengawasan sistem komitmen, hal ini sejalan dengan pendapat Dessler.

d. Faktor- faktor yang enjadi hambatan dan Pendukung pengawas madrasah pada implementasi P.M.A. Nomor 31 Tahun 2013 dalam meningkatkan kinerja guru

Dalam temuan ada beberapa hambatan yang dialami oleh pengawas dalam menjalankan tugasnya diantaranya adalah Kompetensi pengawas yang masih lemah pada bidang penelitian dan pengembangan, dukungan sarana dan prasarana untuk kepentingan tupoksi pengawas, dukungan dari biroksari yang sangat kurang. Misalnya untuk tingkat kota, masih belum jelas posisi atau keberadaan struktur organisasi kepengawasan pada Unit Organisasi Pendidikan Madrasah Kota tersebut. Beban kerja pengawas yang cukup banyak, ditambah lagi dengan peran pengawas di luar karir sebagai assesor Sekolah BAN-S/M Jawa Barat. Adanya kesenjangan dan keseganan dalam mensupervisi kepala sekolah dan guru ketika usia dan pengalaman kepala sekolah dan guru tersebut lebih senior dibandingkan dengan pengawas itu sendiri, pengawas merasa terbatas dalam menyampaikan substansi materi, ketika guru bertanya tentang isi materi dan berharap ada pengembangan dari materi tersebut, karena latar belakang dari pengawas tersebut berbeda mapel yang diampunya. Dari semua hambatan yang dialami pengawas selalu menganalisis dan mengevaluasi untuk kemudian dapat dikembalikan kepada fungsi pengawas itu sendiri dalam pendidikan. Sesuai fungsi pengawas yaitu pengendalian, pengendalian disini sebagai usaha yang sistematik dari manajemen untuk mencapai tujuan dengan langkah perbaikan ke arah yang lebih efektif dan efisien, hal ini sejalan dengan pendapat Usury dan Hammer. Selain faktor penghambat tentunya ada beberapa faktor dominan yang menjadi kekuatan pengawas dalam menjalankan tugasmya yakni, PMA No. 31 Tahun 2013 dan pedoman pedoman kepengawasan lainnya. Kompetensi pengawas yang cukup mumpuni dan menyadari penuh akan tupoksinya sebagai pengawas, berperan aktif sebagai motivator, inovator, assesor, dan sebagai kolaborator para guru dan kepala madrasah. Dengan bekal keaktifan pengawas sebagai asesor Sekolah BAN-S/M Jawa Barat selalu mendapatkan informasi yang lumayan cepat, dan dapat secara langsung disosialisasikan apa yang harus disiapkan ketika akan menghadapi akreditasi, atau penilaian kinerja guru. Peran pengawas sebagai motivator assesor dan sebagai kolaborator tertuang dalam PMA No. 13 Tahun 2013 tentang beberapa kompetensi yang harus dimiliki oleh pengawas.

e. Solusi pengawas madrasah pada Implementasi P.M.A. Nomor 31 tahun 2013 dalam meningkatkan kinerja guru.

Peran pengawas yang begitu penting untuk meningkatkan kualitas akademik maupun manajerial harus mampu mengatasi dan memberikan solusi atas segala hambatan dan dapat memanfaatkan sebaik baiknya potensi positif yang mendukung kinerjanya. Pengawas harus selalu meningkatkan kompetensi diri sebagai pengawas dengan terus belajar dan mengikuti diklat kepengawasan, serta mengadakan study banding dengan pokjawas kota lain. Bukan hanya menuntut dan menilai kinerja guru lebih baik, tapi juga harus mampu meningkatkan kemampuan dan kompetensinya sebagai pengawas. Memaksimalkan forum MGMP dan kelompok binaan, berkoordinasi dengan Pokjawas Kota Bandung membuat jaringan yang kuat antara POKJAWAS, Seksi PAIS, dan MGMP dalam membuat program peningkatan 
profesionalitas Guru dan Pengawas. Dalam hal ini pengawas telah mampu meningkatkan SDM dirinya yang berperan menunjang proses pendidikan guna mendukung ketercapaian mutu madrasah seperti yang tertuang pada PP nomor 19 tahun 2005 pasal 55 dan Undang Undang nomor 20 tahun 2003 tentang sisdiknas pasal 39 ayat 1 .

\section{SIMPULAN DAN SARAN}

\section{A. Simpulan}

Berdasarkan Peneltiian yang telah dilakukan, adapun kesimpulan sebagai berikut:

1. Dalam membuat perencanaan pembimbingan pembinaan pengembangan pengawas selalu mengacu pada Pedoman Kerja Pengawas yang tercantum dalam PMA No. 31 Tahun 2013 yang diatur dalam Buku Pedoman khusus kepengawasan yaitu (1) Program Tahunan dan Program Semester Rencana Pengawasan Akademik dan Rencana Pengawasan Manajerial; (2) Instrumen Monitoring dan Evaluasi Kepengawasn (3) Pedoman Penilaian kinerja guru dan kepala madrasah

2. Rincian Pelaksanaan tupoksi kompetensi Pengawas pada PMA No. 31 tahun 2013 yang di laksanakan pada MAS Al Inayah dan MAS Nurul Iman sudah dilakukan dengan baik terutama dalam melakukan upaya meningkatkan kinerja guru, yakni Pembinaan kepada guru (Kompetensi pedagogis, profesional, kepribadian, dan sosial) b). Pemantauan kinerja guru (Standar Kelulusan, Standar isi, Standar Proses, Standar Penilaian) c). Penilaian Kinerja Guru (PKG) d). Pembimbingan dan pelatihan profesional guru.

3. Evaluasi yang dilakukan pengawas sesuai PMA No. 31 Tahun 2013 sebagai koreksi terhadap hasil pelaksanaan program pengawasan, evaluasi hasil pelaksanaan program pengawasan yang dilakukan pengawas pada kinerja guru yaitu a). Melaksanakan evaluasi hasil pembinaan guru dan kepala madrasah. b). Melaksanakan evaluasi pelaksanaan penilaian kinerja guru dan/atau kepala.

4. Faktor-faktor yang menjadi kelemahan dan hambatan sebagai pengawas Madrasah pada implementasi PMA No. 31 Tahun 2013 dalam meningkatkan kinerja guru adalah Kompetensi pengawas yang masih lemah pada pengembangan bidang penlitian. Dukungan sarana dan prasarana untuk kepentingan tupoksi pengawas, Dukungan dari biroksari yang sangat kurang. Misalnya untuk tingkat kota, masih belum jelas posisi atau keberadaan struktur organisasi kepengawasan pada Unit Organisasi Pendidikan Madrasah Kota tersebut.

5. Sedangkan Faktor-faktor yang menjadi kekuatan dan pendukung pengawas Madrasah pada implementasi PMA No. 31 Tahun 2013 dalam meningkatkan kinerja guru adalah: PMA itu sendiri sebagai pedoman pengawas dalam menjalankan tufoksinya, serta kompetensi pengawas yang cukup mumpuni pada bidang lain dan menyadarai penuh akan tupoksinya sebagai pengawas, berperan aktif sebagai motivator, inovator, assesor, dan sebagai kolaborator para guru dan kepala madrasah.

\section{B. Saran}

Adapun saran penelitian yang diberikan oleh peneliti kepada pengawaa MA yaitu PMA No. 31 Tahun 2013 harus selalu dijadikan landasan dan pedoman dalam melaksanakan tugas pokok dan fungsi baik dalam perenacanaan, pelaksanaan maupun evaluasi program pembimbingan di sekolah dan bahan evaluasi dalam pelaksanaan kepengawasan, pada bagian mana saja yang harus ditingkatkan dan bagian apa saja yang harus diperbaiki terkait dengan peningkatan kinerja guru.

\section{DAFTAR RUJUKAN}

Alma Buchori. 1992. Manajemen Pemasaran dan Pemasaran Jasa. Bandung: Alfabeta.

Amin Widjaja Tunggal. 1993. Manajemen Suatu Pengantar. Jakarta: Renika Cipta.

Anisah. 2017. Tesis Pelaksanaan Kebijakan Supervisi Pengawas PAI di Kabupaten Rembang. Pascasarjana IAIN Salatiga, Rembang.

Anthony dan Vijay Govindarajan. 1998. Management Control System. Mc Clelland Grawhill.

Arikunto, Suharsimi. 2004. Dasar-dasar Supervisi. Jakarta: Rineka Cipta. 
Arikunto, Suharsimi. 2008. Manajemen Pendidikan. FIP Universitas Negeri Yogyakarta: Aditya Media

Barnawi dan Muhammad Arifin. 2012. Kinerja Guru Profesional. Bandung: Alfabeta.

Edward Sallis. 2011. Total Quality Management in Education (Manajemen Mutu Pendidikan), terj. Ahmad Ali Riyadi \& Fahrurrozi: Yogyakarta.

Emrin. 2010. Metodologi Penelitian Kualitatif Analisis Data. Jakarta: PT Rajagrafindo Persada

Erni Tisnawati Sule, 2005, Pengantar Manajemen, Jakarta, Kencana Prenada Media Group.

Faridah Ismu, 2007, Tentang Peran Pengawas Dalam Meningkatkan Kinerja Guru Madrasah Ibtidaiyah Di Kabupaten Wonogiri Tahun Pelajaran 2006/2007. Wonogiri,

Fattah Nanang, 2004, Landasan Manajemen Pendidikan, Bandung PT. Remaja Rosdakarya.

Gary Dessler,1998, Management : Principles and Practices for Tomorrow's Leaders. International Third Edition, Pearson Education,Inc,

George. R. Terry, Prinsip-prinsip Manajemen, 1993, Terj. J. Smith, Jakarta, Bumi Aksara.

Hadi, Sutrisno.1995. Metodologi Research II. Yogyakarta: Andi Offset

Harahap Sofyan Syafri, 1992, Akuntansi, Pengawasan dan Manajemen dalam Perspektif Islam , Jakarta Fe Universitas Trisakti.

Hasibuan Malayu S.P, 2005, Manajemen, Dasar, Pengertian dan Masalah, Bumi Aksara, Jakarta

M. Herujito Yayat 2001, Dasar-dasar Manajemen, Jakarta Grasindo.

Ihsanuddin, Ahmad 2015. Implementasi Supervisi Pengawas PAI Dalam Meningkatkan Kompetensi Pendagogik Guru PAI SD Di Kecamatan Berbah Sleman. IAIN Surakarta.
Imron, Ali. 2012. Supervisi Pembelajaran Tingkat Satuan Pendidikan. Jakarta: PT Bumi Aksara

Isnen, 2011, Partisipasi Masyarakat Terhadap Peningkatan Mutu Pendidikan (Studi Analisis Terhadap Implementasi Manajemen Berbasis Sekolah di MI Miftahul Huda Jati Karangan Trenggalek), MSI UII pada tahun

Kementerian Agama RI, 2011, Pedoman Penyelenggaraan Kelompok Kerja Pengawas, Jakarta.

Kementrian Agama RI, Al Qur'an dan Terjemahnya, Jakarta: PT. Sinergi Pustaka Indonesia.

Kementrian Agama, 2013, PMA no 90 tahun 2013, Kurikulum Madrasah Aliyah, Jakarta

Kementrian Agama, 2019, KMA nomor 184 tahun 2019 tentang Pedoman Implementasi Kurikulum pada Madrasah. Jakarta

Kusuma Handri, 2011, Supervisi Pengawas Pendidikan Agama Islam dalam Meningkatkan Kualitas Guru Pendidikan Agama Islam (Penelitian Terhadap Guru di Kecamatan Tegalrejo Kota Yogyakarta), Yogyakarta.

Made Pidarta, 1988, Manajemen Pendidikan Indonesia , Jakarta: Bina Aksara,

Mahmuddin, 2004, Manajemen Dakwah Rasulullah (Suatu Telaah Historis Kritis) Jakarta: Restu Ilahi,

Moleong, Lexy J, 2007, Metodologi Penelitian Kualitatif, Bandung: Remaja Rosdakarya.

Mulyana, Deddy. Metode penelitian kualitatif, paradigma baru ilmu komunikasi dan ilmu sosial lainnya. Bandung: Remaja Rosdakarya.

Mulyasa. 2009, Standar Kompetensi dan Sertifikasi Guru. Bandung: PT Remaja Rosdakarya.

Munir Misbahul,2008 Peran Supervisor Dalam membina Profesi Guru (Penelitian terhadap Guru Madrasah Ibtidayah di Kecamatan Sodonghilir Kabupaten Tasik Malaya, Tasikmalaya. 
Naedi, Nur. 2014. Pengawas Pendidikan Teori Dan Praktik. Depok: PT Rajagrafindo Persada

Nasikha, 2012, penelitian tentang Hubungan Supervisi Akademik Terhadap Peningkatan Kinerja Guru Madrasah Ibtidaiyyah di Kecamatan Tarub Kabupaten Tegal, Tegal

Noer Rohmah,2019 Pengawasan Pendidikan dalam perspektif Al-Quran dan Hadits, Malang Tarbiyatuna: Jurnal Pendidikan Ilmiah Vol. 4 No. 2.

Peraturan Mentri Agama no 2 TAHUN 2012, Tentang Pengawas Madrasah dan Pengawas Pendidikan Agama Islam Pada Sekolah

Peraturan Mentri Agama no 31 TAHUN 2013, Tentang Pengawas Madrasah dan Pengawas Pendidikan Agama Islam Pada Sekolah

Pidarta Made, 1998, Manajemen Pendidikan Indonesia , Bina Aksara, Jakarta .

Piet A. Sahertian, 1991 , prinsip dan teknik supervisi pendidikan, Surabaya: Usaha Nasional.

Prabu Mangkunegara A.A Anwar, 2004, Manajemen Sumber Data Perusahaan, PT. Refieka Aditema, Bandung

Purwanto, M. Ngalim. Administrasi dan Supervisi Pendidikan. Bandung: PT Remaja Rosdakarya, 2009.
Sallis Edward, 2011, Total Quality Management in Education (Manajemen Mutu Pendidikan), terj. Ahmad Ali Riyadi \& Fahrurrozi, Yogyakarta IRCiSoD.

Shaleh, Abdul Rachman. 2006. Pendidikan Agama Dan Pembangunan Watak Bangsa. Jakarta: PT Raja Grafindo Persada

Sugiyono. 2015. Metode Penelitian Kuantitatif, Kualitatif, dan R\&D, Bandung: Alfabeta.

Sukarna. 2011. Dasar-Dasar Manajemen. Bandung: CV. Mandar Maju.

Syakir Ahmad trj. Suharlan, Suratman , 2016, Mukhtasar tafsir Ibnu Katsir (jilid 5), Darus Sunnah, Jakarta.

Tim Dosen Administrasi Pendidikan UPI. 2012. Manajemen Pendidik. Jogjakarta: Ar-Ruzz Media.

Tim Penyusunan Kamus Pembinaan dan Pengembangan Bahasa. kamus besar Bahasa Indonesia edisi ke-2. Jakarta: Balai Pustaka

Torang, Syamsir. 2013. Organisasi dan Manajemen (Perilaku, Struktur, Budaya \& Perubahan Organisasi. Alfabeta. Bandung.

Undang-Undang Republik Indonesia Nomor 20 Tahun 2003 tentang Sistem Pendidikan Nasional,http://kemenag.go.id/file/dokume n/UU2003.pdf 